ANUVA Volume 1 (1): 19-32, 2017

Copyright C2017, ISSN: 2598-3040 online

Available Online at: http://ejournal.undip.ac.id/index.php/anuva

\title{
Pengelolaan TBM Sebagai Sarana Meningkatkan Minat Baca Masyarakat
}

\author{
Sri Ati Suwanto ${ }^{1 *}$ \\ ${ }^{1}$ Program Studi Ilmu Perpustakaan, Fakultas Ilmu Budaya, Universitas Diponegoro, \\ Jl. Prof. Sudharto, SH, Tembalang, Semarang, Indonesia. \\ *) Korespondensi: tikasuwanto@gmail.com
}

\begin{abstract}
This study was conducted with the aim of knowing whether TBM management can increase reading interest. The research design used is quantitative with the type of literature review, then processed by descriptive analytics. The results showed that Community Reading Garden could be used as a means to faster interest in reading. The existence of Taman Baca is very important because it is very close to the community at the grassroots. Therefore it needed to be managed well, in accordance with theories of library management that could be used as a guideline for Taman Baca Masyarakat.
\end{abstract}

Keywords: TMB; Community reading park; Library Management

\begin{abstract}
Abstrak
Penelitian ini dilakukan dengan tujuan untuk mengetahuai apakah pengelolaan TBM dapat meningkatkan minat baca masyarakat. Desain penelitian yang digunakan adalah kuantitatitif dengan jenis Literatur review, kemudian diolah secara deskriptif analitik. Hasil penelitian menunjukkan bahwa Taman Bacaan Masyarakat dapat digunakan sebagai sarana untuk menumbuhkan minat baca. Keberadaan Taman Baca sangat penting karena sangat dekat dengan masyarakat di akar rumput. Oleh karena itu perlu dikelola dengan baik, sesuai dengan teori-teori pengelolaan perpustakaan yang dapat digunakan sebagai pedoman Taman Baca Masyarakat.
\end{abstract}

Kata Kunci : TMB; Taman baca Masyarakat; Pengelolaan Perpustakaan. 


\section{Pendahuluan}

Dalam era globalisasi ini, sudah banyak perpustakaan-perpustakaan di Indonesia yang telah berkembang dengan baik, khususnya perpustakaan-perpustakaan perguruan tinggi dan perpustakaan- perpustakan yang dulunya termasuk dalam sekolah berstandar nasional dan sekolahsekolah swasta yang bonafit, maupun perpustakaan instansi yang memikirkan perlunya perpustakaan untuk lembaganya. Tetapi tidak sedikit perpustakaan sekolah yang sekedar ada untuk memenuhi syarat diakuinya sekolah tersebut. Kalau perpustakaan tidak menerapkan konsep manajemen yang baik, maka perpustakaan dapat digantikan perannya sebagai sumber informasi oleh tempat-tempat lain, seperti warung-warung internet. Karena warung-warung internet telah dikenal masyarakat dapat memberikan sumber informasi dengan cepat. Sekarang ini terjadi kecenderungan anak-remaja lebih senang mengakses internet daripada ke perpustakaan.

Kondisi perpustakaan di perkotaan dan perpustakaan perguruan tinggi sangat berbeda dengan kondisi di Taman Bacaan Masyarakat (TBM) yang saat ini juga tumbuh subur di berbagai daerah. Meskipun keberadaan Taman Baca di kota Semarang saat ini berkembang pesat, tetapi dalam pengelolaannnya taman baca ini belum tertata dengan baik. Taman baca tersebut hanya memajang koleksi yang mereka punya di rak-rak kayu atau bahan lain yang ada. Permasalahan ini ditambah dengan bentuk pengelolaan terhadap sarana dan prasarananya yang belum tertata dengan rapi.

Taman baca yang ideal yaitu taman baca yang memiliki standar koleksi perpustakaan, standar sarana dan prasarana, standar pelayanan, standar tenaga, standar penyelenggaraan, dan standar pengelolaan. Permasalahan umum yang terjadi adalah manajemen taman baca rata-rata belum memenuhi standar di atas, dikarenakan beberapa keterbatasan yang dimiliki. Keterbatasan itu dipengarui oleh kemampuan pengelola dan kondisi sosial ekonomi dan politik masyarakat setempat yang belum mendukungnya.

Padahal keberadaan Taman Baca sangat penting karena sangat dekat dengan masyarakat di akar rumput. Bila didasarkan urutan pada kepentingan, fungsi utama TBM adalah pelayanan pemustaka di akar rumput, kepada para karangtaruna, anak-anak putus sekolah di perkampunganperkampuingan

Peran Taman Bacaan Masyarakat (TBM) dalam menumbuhkan minat membaca dan menulis pada masyarakat adalah suatu upaya mendayagunakan sumberdaya insani yang terlibat dalam mendukung aktivitas pengelolaan kegiatan TBM sehingga mampu mendorong minat masyaratak untuk gemar membaca dan menulis. Pengelolaan taman baca diperlukan karena dalam rangka menunjang proses belajar masyarakat dan menumbuhkan minat baca bagi masyarakat sehingga dapat meningkatkan kualitas masyarakat. Oleh karena itu TBM perlu dikelola dengan baik, dengan menggunakan sitem yang abik, yang saat ini disenangi generasi muda. Masalahnya adalah apakah pengelolaan TBM dapat dipakai sebagai sarana meningkatkan minat baca masyarakat? Oleh karena 
itu kajian ini dilakukan dengan tujuan untuk mengetahuai apakah pengelolaan TBM dapat meningkatkan minat baca masyarakat. Karena pengaruh globalisasi, generasi muda saat ini lebih tertarik segala sesuatu yang terhubung internet, karena lebih cepat dan lebih praktis. Oleh karena itu tulisan ini difokuskan pada pengelolaan TBM secara elektronis.

Definisi TBM menurut Departemen Pendidikan dan Kebudayaan (2006) adalah sebuah tempat atau wadah yang didirikan dan dikelola baik oleh masyarakat maupun pemerintah untuk memberikan akses layanan bahan bacaan bagi maasdewrfegrgsyarakat sekitar sebagai sarana pembelajaran seumur hidup dalam rangka peningkatan kualitas hidup masyarakat di sekitar TBM. TBM memiliki peran yang sangat strategis dalam upaya mencerdaskan bangsa serta meningkatkan kwalitas manusia Indinesia khususnya masyarakat lingkungannya. Sebagai salah satu tempat pelayanan bahan pustaka memiliki kepentingan pelayanan yang langsung menyentuh kebutuhan masyarakat. Hal ini dikarenakan kedudukan TBM dilihat dari wilayah kedudukannya berada di bawah perpustakaan desa/ kelurahan. Artinya, dalam sebuah desa mungkin sekali terdapat lebih dari satu TBM. Disamping itu pengadministrasian pembukuan TBM lebih sederhana dibandingkan dengan perpustakaan desa2. Taman Bacaan Masyarakat mempunyai tanggung jawab, wewenang, dan hak masyarakat setempat dalam membangunnya, mengelola dan mengembangkannya. Dalam hal ini perlu dikembangkan rasa untuk ikut memiliki (sense of belonging), ikut bertanggung jawab (sense of responsibility) dan ikut memelihara (to take care of), (Sutarno, 2006 : 19). Untuk dapat melakukan pengelolaaan yang baik perlu mengetahui pengorganisasian TBM.

Proses pengorganisasian TBM akan berjalan dengan baik apabila memperhatikan prinsipprinsip organisasi sebagai landasan gerak. Prinsip-prinsip organisasi menurut Kementerian Pendidikan dan Kebudayaan ( 2013) adalah:

1) Perumusan tujuan jelas diketahui oleh seluruh elemen yang terkait dalam organisasi itu.

2)Pembagian kerja jelas untuk mencapai efektifitas dan efisiensi.

3)Adanya batas-batas kewenangan yang jelas pada masing-masing orang atau kelompok.

4)Adanya kesatuan komando sehingga menghindari dualisme pengaruh dan kekuasaan.

5) Adanya kordinasi untuk menyatukan langkah kerja.

Dalam melakukan pengorganisasian TBM, perlu mengerti teori dasar manajemen. Kemudian sekarang apa definisi manajemen? Ada beberapa definisi mengenai manajemen yang diberikan oleh para ahli, antara lain :

Dhawan (2014) menyebutkan Manajemen perpustakaan melibatkan fungsi seperti perencanaan, pengorganisasian, memimpin, dan mengendalikan. Fungsi-fungsi ini berdasarkan teori Terry ( dalam Suwanto, 2009) yang melihat manajemen berdasarkan madzab proses, yaitu : Perencanaan, Pengorganisasian, Menggerakkan, dan Pengawasan, atau yang biasa disingkat 
dengan POAC (planning, Organizing, Actuating, dan Controlling).

Dengan demikian dapat disimpulkan bahwa manajemen adalah suatu proses perencanaan, pengorganisasian, menggerakkan serta mengawasi aktivitas-aktivitas lembaga dalam rangka mencapai tujuan dengan memanfaatkan sumber daya manusia, informasi dan sistem, secara efektif dan efisien.

\section{Manajemen TBM.}

Menurut Sinaga (2005) perbandingan Taman Bacaan Masyarakat dengan perpustakan ditinjau dari sifatnya adalah Taman Bacaan Masyarakat sifatnya lebih in formal dan cakupan tidak terlalu luas dibanding perpustakaan sedangkan perpustakan sifatnya lebih formal dan cakupannya lebih luas. Dengan dmikian manajemen TBM hampir sama atau kalau boleh dikatakan sama dengan manajemen perpustakaan, hanya tentunya lebih sederhana. Manajemen tersebut terdiri dari

\section{Pengorganisasian}

TBM dalam melaksanakan kegiatannya melakukan langkah-langkah pengorganisasian dengan tujuan untuk menyatukan langkah-langkah dari seluruh kegiatan yang dilaksanakan oleh elemenelemen dalam pengelolaan TBM supaya tidak terjadi tumpang tindih dalam melaksanakan tugas masing-masing pengelola sesuai dengan jabatannya.

Menurut Sinaga (2005) proses pengorganisasian TBM memakai landasan gerak sbb :

a) Perumusan Tujuan

b) Pembagian Kerja

c) Pembagian Wewenang

d) Kesatuan Komando

e) Koordinasi

Koordinasi merupakan proses pengintegrasian tujuan pada satuan-satuan yang terpisah dalam TBM untuk mencapai tujuan secara efesien.

Sesuai dengan tugas-tugas yang dilakukan anggotanya, maka TBM melakukan pengaturan organisasinya untuk menunjukkan setiap tugas orang yang berada dalam organisasi pengelola TBM sehingga jelas batas-batasnya, hubungannya, wewenang, dan tanggungjawabnya dalam usaha mencapai tujuan yang diinginkan. Dengan pengorganisasian yang baik, maka TBM diharapkan dapat meningkatkan minat baca masyarakat. Oleh karena itu penelitian ini penting dilakukan untuk menganilis pengelolaan TBM sebagai sarana untuk meningkatkan minat baca.

\section{Metode}

Penelitian ini dilakukan dengan menggunakan desain penelitian kualitatif dengan metode literature review atau studi literatur. Studi literatur dalam penelitian kualitatif berbeda 
penekanannya dengan penelitian kuantitatif. Keterlibatan teori dalam penelitian kualitatif hanya sebatas permasalahan penelitian, tetapi tidak berfungsi sebagai sebagai identifikasi dari arah penelitian, tujuan penelitian dan pertanyaan penelitian yang diajukan. Hal ini karena yang digunakan sebagai dasar pijakan adalah sudut pandang dari subyek penelitian dalam memandang suatu fenomena atau memaknai pengalaman subyeknya (Herdiansyah, 2010). Karena data yang didapat adalah data kualitatif, maka penelitian ini akan dianalisis secara deskriptif analitik.

\section{Pembahasan}

Salah satu intrumen untuk membangkitkan budaya gemar belajar melalui masyarakat gemar membaca adalah dengan tersedianya Taman Bacaan Masyarakat (TBM). TBM adalah suatu lembaga/tempat yang menyediakan bahan bacaan yang dibutuhkan oleh masyarakat, dan sebagai tempat penyelenggaraan program pembinaan kemampuan membaca dan belajar masyarakat, (Kusnadi, 2005). Diselenggarakannya taman bacaan selain untuk mewujudkan masyarakat gemar membaca, juga dimaksudkan untuk mendukung pendidikan keaksaraan. (Depdiknas, 2005).

Program Taman Bacaan Masyarakat (TBM) telah dimulai sejak tahun 1992/1993. Kehadiran TBM merupakan pembaharuan dari Taman Pustaka Rakyat (TPR) yang didirikan oleh Pendidikan Masyarakat pada tahun limapuluhan. Program TBM ini bertujuan untuk meningkatkan minat baca dan budaya baca masyarakat. Oleh karena itu keberaadaan TBM sangat penting sebagai sarana belajar masyarakat. Untuk itu kemampuan, keterampilan dan kinerja pengelola harus ditingkatkan sehingga dapat mengelola TBM sebagaimana mestinya.

TBM adalah sebuah lembaga yang menyediakan bahan bacaan yang dibutuhkan oleh masyarakat. Sebagai tempat penyelengaraan pembinaan kemampuan membaca dan belajar, sekaligus sebagai tempat untuk mendapatkan informasi bagi masyarakat. Pengelola TBM adalah mereka yang memiliki dedikasi dan kemampuan teknis dalam mengelola dan melaksanakan layanan kepustakaan kepada masyarakat. Sedangkan bahan pustaka adalah semua jenis bahan bacaan dalam berbagai bentuk media.

Taman Bacaan Masyarakat (TBM) merupakan salah satu kegiatan dari program peningkatan budaya baca dan pembinaan perpustakaan yang digalakkan oleh Direktorat Dikmas, Ditjen Pendidiikan Non Formal dan Informal (PNFI) sebelumnya Ditjen Pendidikan Luar Sekolah Depdiknas. Dalam jangka panjang, PNFI ingin menciptakan masyarakat pembelajar melalui peningkatan budaya baca. Untuk mencapai keinginan tersebut, diperlukan adanya kesediaan masyarakat untuk membentuk taman bacaan. Dari sini pada akhirnya berkembang menjadi perpustakaan. Depdiknas berupaya menyiapkan bahan bacaan yang bisa diakses oleh masyarakat sesuai kebutuhan di daerah masing-masing.

Di jalur pendidikan nonformal keberadaan TBM dianggap sangat strategis dan merupakan ujung tombak dalam memasyarakatkan gemar dan kebiasaan membaca sehingga menjadi salah satu ciri kebudayaan masyarakat setempat. Oleh karena itu, Pemerintah berupaya 
mengembangkan dan memberdayakan TBM sehingga menjadi wadah yang mampu menyediakan berbagai bahan belajar yang dibutuhkan masyarakat serta sekaligus sebagai tempat penyelenggnraan pembinaan kemampuan membaca dan belajar serta tempat untuk mendapatkan berbagai informasi yang diperlukan masyarakat. Oleh karena itu, TBM perlu dikelola oleh mereka yang memiliki dedikasi dan kemampuan teknis dalam mengelola dan melaksanakan layanan kepustakaan kepada masyarakat di samping menyediakan berbagai jenis bahan bacaan. Dalam rangka mewujudkan masyarakat Indonesia pembelajar sepanjang hayat diperlukan bahan bacaan yang disediakan oleh taman bacaan masyarakat.

Para warga belajar yang telah menyelesaikan pendidikan di kelompok belajar keaksaraan (aksarawan baru) perlu dibina sehingga tidak menjadi buta aksara kembali akibat ketiadaan sarana pendukung pemelihara kemampuan membaca. Disamping itu dalam keaksaraan ada yang mempromosikan keaksaraan sebagai "keaksaraan kritis" yaitu masyarakat penyandang buta aksara disadarkan untuk mengerti dan memahami isu-isu yang sedang berkembang dalam lingkungannya dan memberdayakan mereka untuk dapat mewujudkan perubahan, serta membebaskan mereka dari penindasan baik karena factor ekonomi, social, budaya politik atau factor lainnya. Keaksaraan kritis bertujuan untuk membaca dunia disekelilingnya dan mengubahnya sesuai dengan cara pandang mereka dan masyarakat sekitarnya (Bhola, 1994).

TBM merupakan jantung pendidikan masyarakat, dengan bahan bacaan yang disediakan diharapkan mampu memotivasi dan menumbuhkembangkan minat dan kegemaran membaca bagi aksarawan baru, warga belajar, dan masyarakat. Dengan tumbuhkembangnya minat dan kegemaran membaca, maka membaca merupakan suatu kebiasaan yang mesti dilakukan tiap hari sebagaimana memenuhi kebutuhan hidup. Ketika ini sudah terjadi maka akan lebih memudahkan pengelolaan TBM di tengah-tengah masyarakat kita. Strategi pendirian TBMdan pelaksanaan program-programnya agar menuju pada pengelolaan yang kreatif dan produktif, menurut Departemen Pendidikan Nasional (2008) maka pengelola harus :

1) Memiliki Pengetahuan akan kebutuhan masyarakat

Pengelola TBM harus memahami dan memiliki pengetahuan akan kebutuhan masyarakat sekitarnya sehingga buku-buku yang ditampilkan di TBM benar-benar dibutuhkan masyarakat. TBM yang didirikannya diperlukan masyarakat.

2) Melakukan kerjasama, dan pendekatan dengan tokoh masyarakat.

Lakukan kerjasama dengan tokoh masyarakat sebagai orang yang mengetahui seluk beluk budaya, sosial, ekonomi dan peradaban masyarakat sebagai acuan dalam memilah buku yang akan disajikan di TBM

3) Melakukan identifikasi kebutuhan TBM

Telisik bahan-bahan kebutuhan masyarakat terkait bahan bacaan dan 
pendukungannya, minat bacanya, harapan masyarakat akan bahan bacaan, lokasi yang strategis dan calon anggotanya.

4) Terbuka kepada masyarakat sekitar

Usahakan bahwa pendirian TBM dilakukan transparan, dilakukan bersama-sama masyarakat dan melibatkan masyarakat dengan partisipasi mutlak dari mayarakat.

5) Sosialisasi kepada masyarakat tentang nilai- nilai yang akan diusung oleh TBM

Sebarkan nilai-nilai yang akan diusung oleh TBM dalam pendiriannya. Aspirasi, nilai dan budaya masyarakat harus menjadi acuan dalam menentukan dan mendirikan TBM.

6) Melibatkan masyarakat dalam kepengurusan dan pengelolaan

Melibatkan masyarakat dalam pendirian dan kepengurusan TBM sangat diperlukan untuk menumbuhkan rasa memiliki. Berikan keleluasan pada masyarakat untuk berpartisipasi dalam pengelolaan TBM di tempatnya.

Taman Bacaan Masyarakat merupakan salah satu instrumen penting untuk menunjang pelaksanaan pendidikan nonformal (Departemen Pendidikan Nasional, 2008). Taman Bacaan Masyarakat yang diselenggarakan oleh masyarakat dan untuk masyarakat bertujuan untuk memberi kemudahan akses kepada warga masyarakat untuk memperoleh bahan bacaan. Taman Bacaan Masyarakat berperan dalam meningkatkan minat baca, menumbuhkan budaya baca, dan cinta buku bagi warga belajar dan masyarakat. Secara khusus taman bacaan masyarakat dimaksudkan untuk mendukung gerakan pemberantasan buta aksara yang antara lain karena kurangnya sarana yang memungkinkan para aksarawan baru dapat memelihara dan meningkatkan kemampuan baca tulisnya. Lebih lanjut taman bacaan masyarakat juga ditujukan untuk memperluas akses dalam memberikan kesempatan kepada masyarakat akar rumput.

Di beberapa kota ada perpustakaan ramah anak meskipun jumlahnya belum banyak dan belum berskala nasional. Kota Bandung juga telah didirikan Perpustakaan Anak Salman (PAS) yang dibangun atas inisiatif Pembinaan Anak-Anak Salman (PAS) ITB dengan pendanaan dari alumni Salman ITB. Selain buku anak, fasilitas ini juga akan dilengkapi multimedia untuk anak. Di Surabaya, tepatnya di Jalan Mayjen Sungkono, terdapat perpustakaan anak yang merupakan cabang dari Perpustakaan Wilayah Propinsi Jawa Timur, yang didirikan khusus untuk anak-anak. Fasilitas yang dibangun meliputi ruang koleksi, ruang baca, ruang bermain, ruang mendongeng, ruang audiovisual, ruang komputer, konter sirkulasi, lobby dan fasilitas pendukung lainnya. Konsep yang digunakan dalam perancangan adalah taman bermain (Shofaussamawati, dalam Khoirudin, dkk.,2016).

Menilik dari berbagai contoh perpustakaan anak tersebut di atas, ada beberapa hal yang 
penting untuk diperhatikan dalam menciptakan minat baca sejak dini. Kemuculan Taman Bacaan Masyarakat (TBM) menjadi embrio pendidikan alternatif (baca : informal-nonformal) untuk mendorong Gerakan Membaca masyarakat secara swadaya. Seiring dengan adanya dukungan dari pemerintah terhadap berbagai TBM yang ada, muncul juga nama nama alternatif yang menggeser istilah perpustakaan. Dari berbagai yang muncul tersebut, sebut saja ada Pustaka Bergerak, Rumah Baca, Rumah Buku, Cafe Buku, Sanggar Baca, Kampung Baca dan sebagainya.

Dengan beragamnya kemunculan TBM tersebut, masyarakat kini lebih mudah untuk membaca buku sambil santai, bercanda dan dengan nyaman. Di sini orang bisa membaca buku sambil berdiskusi dan berbagi ide dengan terbuka.

Berdasarkan berbagai penelitian, diantaranya penelitian Ruhaena 2012 ( dalam Khoirudin, 2016) mendapatkan hasil bahwa anak-anak usia 5-6 tahun kurang memiliki minat dan kebiasaan membaca. Hal ini terjadi karena orang tua lebih banyak mengajarkan keterampilan baca tulis, menyediakan buku dan alat-alat tulis, dari pada mengajak anak membaca cerita, dan bermain kartu/gambar serta membeli buku di toko-toko buku. Cara yang dilakukan oleh orang tua ini terlalu tekstual dengan pendekatan kognitif yang menuntut konsetrasi sehingga kurang menyenangkan bagi anak. Maka dari itu perlu ada penangan khusus dengan mengembangkan taman baca yang tidak lagi sekedar tempat mengajarkan anak membaca dan menulis tetapi menjadi tempat yang dapat mendorong stimulasi anak agar memiliki minat dan kegemaran membaca.

Penelitian Nugroho dan Maureen (2012) di Taman Bacaan Masyarakat Rusun Bangunrejo Surabaya menemukan hasil bahwa TBM tersebut memberikan bimbingan belajar kepada anak-anak sekolah yang memiliki tugas dari sekolahnya. Di samping itu juga memberikan bimbingan belajar kepada anak-anak TBM serta berperan menyediakan akses informasi dari berbagai literatur untuk menyelenggarakan pendidikan nonformal. Di samping itu TBM Rusun Bangunrejo sering menyelenggarakan kegiatan perlombaan untuk mengetahui minat dan bakat anak-anak sekitar Rusun, seperti lomba melukis dan lomba mewarnai. Dengan adanya berbagai lomba di TBM, anakanak akan tertarik melihat-lihat koleksi yang ada di TBM, dan akhirnya akan membaca koleksi tersebut.

\section{Menumbuhkan minat baca}

Bagaimana cara menumbuhkan minat baca agar kita selalu senang dan ketagihan membaca? Rahmawan (2013) mengungkapkan ada 8 cara untuk menumbuhkan minat baca, yaitu:

\section{1) Mengalokasikan Waktu Khusus untuk Membaca}

Dengan mengalokasikan waktu10-15 menit secara konsisten kemudian setiap bulannya, demi sedikit bisa meningkatkan kebiasaan membaca buku hingga satu atau dua jam setiap harinya. 


\section{2) Membeli Buku Setiap Minggu}

Dengan membeli buku-buku berkualitas atau recommended setiap pekannya, baik dibaca atau tidak, mau tidak mau masyarakat akan 'dipaksa' untuk membaca, karena kalau tidak dibaca akan merasa sayang.

\section{3) Manfaatkan Waktu Menunggu}

Waktu menunggu bisa dimanfaatkan untuk menumbuhkan kebiasaan membaca. Waktu menunggu dapat ditemui saat kita menunggu bis, sedang ada di angkot, menunggu seseorang untuk bertemu, atau apapun.

\section{4) Memiliki List Buku Populer atau Rekomendasi}

Salah satu alasan kenapa orang malas membaca adalah karena saat kita membaca buku atau apapun itu, kita mendapatkan hal yang kita tidak sukai untuk membacanya. Maka cara yang baik untuk menangkalnya adalah dengan meminta beberapa list buku yang direkomendasikan oleh guru atau dosen yang kemungkinan lebih menarik dan sudah dibuktikan Rahmawan bahwa hal itu ternyata benar, dan diapun senang membacanya.

\section{5) Belajar membaca efektif}

Survey membuktikan saat ini hanya satu dari dua puluh orang yang kemampuan membacanya berkembang sejak SD. Di internet, orang bisa menemukan bagaimana cara membaca dengan lebih baik, cepat, konsentrasi, dan lebih paham. Jika memang kurang, ada lembaga pelatihan yang menyediakan itu. Namun, yang ditekankan adalah, salah satu cara menumbuhkan minat baca adalah dengan belajar membaca efektif yang ternyata sangat jauh berbeda semenjak kita berada di SD dulu.

\section{6) Membaca Saat Istirahat atau Sebelum Tidur}

Hal ini juga bisa dilakukan jika ternyata selama waktu Anda sangat sibuk dan penuh dengan aktivitas. Gunakan waktu istirahat Anda dengan membaca, atau rutinkan membaca buku walaupun sedikit sebelum Anda tidur.

\section{7) Membuat Target Membaca}

Setiap orang sebaiknya punya rencana membaca. Rencana membaca adalah target atau daftar buku apa yang harus ditamatkan untuk dibaca pada minggu atau bulan ini. Rahwawan punya target bahwa setiap bulannya dia menamatkan ( bukan hanya sekedar membaca) sekitar 3-5 buku di luar buku kuliah yang kemudian di resume atau dibuat ringkasannya.

\section{8) Berdiskusi dan Bergabung di Komunitas}


Berdiskusi bisa menjadi cara ampuh untuk tetap menjaga kita tetap semangat membaca. Rahmawan membiasakan di suatu lembaga Training Center. Setiap trainer dan manajemen diwajibkan untuk membedah buku sepekan sekali dan membuat slide presentasinya untuk kemudian didiskusikan dan menjaga semangat membaca.

Sementara itu, Hurlock dalam artikelnya di website bpkpenabur.or.id (dalam Setiawan, 2017) menyebutkan bahwa minat yang berkembang pada anak adalah karena hal berikut ini

- Minat bertumbuh bersamaan dengan perkembangan mental

- Minat bergantung pada kesiapan belajar

- Minat diperoleh dari pengaruh budaya

- Minat dipengaruhi oleh bobot emosi

- Minat adalah sifat egosentrik di semua masa anak-anak

Dari penjelasan singkat tersebut, berarti orang tua perlu melakukan persiapan untuk menumbuhkan minat baca pada anak. Hal-hal tersebut dapat diperoleh dengan salah satunya menciptakan budaya/lingkungan membaca di rumah, serta melibatkan emosi (rasa senang dan enjoy) dalam proses menumbuhkan minat baca mereka.

Menurut Hasyim dalam sebuah artikel di bpkpenabur.or.id Cara menumbuhkan minat baca pada anak dapat dilakukan antara lain dengan cara-cara berikut :

\section{Bacakan buku sejak anak lahir}

Kemampuan membaca sejak dini ternyata tidak berhubungan dengan IQ anak, namun sangat berhubungan dengan suasana rumah dan keluarganya. Anak-anak yang bisa membaca sejak dini ternyata muncul dari keluarga yang memiliki perhatian dan usaha ekstra dalam membantu mereka belajar membaca.

\section{Dorong anak bercerita tentang apa saja yang telah didengar atu dibacanya}

Meminta anak untuk bercerita tentang sesuatu yang telah dibacanya atau didengarnya membuat mereka lebih akrab dengan bahasa dan tutur kata.

\section{Ajak anak ke toko buku atau perpustakaan}

Jadikan toko buku sebagai tempat singgah yang menyenangkan bagi anak dengan membiasakan mereka untuk mengunjunginya. Berikan kepercayaan pada mereka untuk memilih sendiri buku yang mereka minati. Tanamkan sikap selektif dalam memilih buku kepada anak. Dorong pula anak untuk rajin mengunjungi perpustakaan yang bisa mereka akses, baik perpustakaan sekolah maupun perpustakaan umum. 


\section{Beli buku yang menarik minat anak}

Mulailah dari hal yang paling mereka sukai. Hindari untuk memaksa mereka membaca suatu jenis buku yang kurang mereka minati. Perkenalkan pada anak-anak kita bahwa membaca adalah proses yang menyenangkan

\section{Sisihkan uang untuk membeli buku}

Sediakan anggaran khusus untuk membeli buku. Jadikan buku sebagai kebutuhan yang penting bagi anak daripada membelikan anak beberapa jenis mainan yang manfaatnya dipertanyakan. Apalagi buku merupakan harta yang tidak ternilai jika anak mau membacanya. Apa yang terkandung dalam sebuah buku akan menjadi investasi di kepala anak.

\section{Ciptakan perpustakaan keluarga}

Jika memungkinkan, buatlah perpustakaan keluarga di rumah. Tidak harus mewah dan lengkap, mulailah dari yang sederhana dulu. Kumpulkan buku anak dalam satu lemari khusus yang mudah mereka ambil, tidak terlalu tinggi, tersembunyi, apalagi terkunci. Tambahkan karpet yang membuat nyaman.

\section{Hilangkan penghambat seperti televisi atau playstation}

Menonton televisi atau main playstasion bukanlah hobi yang harus dilarang, tapi sebaiknya dibatasi. Supaya waktu anak bisa dialokasikan untuk membaca buku. Orang tua dianjurkan mengendalikan pemakaian televisi, mengingat tayangan-tayangan yang sering kali tidak sesuai untuk dikonsumsi anak.

\section{Beri hadiah/reward yang memperbesar semangat membaca}

Anak akan sangat bersemangat jika diberi penghargaan/hadiah. Penghargaan bisa bersifat materi dan nonmateri. Berikan kata-kata yang positif yang akan membangun rasa percaya diri anak dalam membaca, arahkan dengan sabar serta berikan penghargaan hadiah-hadiah kecil yang membuat anak antusias. Jadikan buku sebagai hadiah (reward) untuk anak.

\section{Jadikan membaca sebagai kebiasaan di keluarga}

Kegiatan membaca setiap hari akan menumbuhkan minat baca anak sekaligus membentuk kebiasaan membaca pada anak. Apabila sibuk, sempatkan lima atau sepuluh menit setiap harinya untuk membacakan cerita kepada anak. Jika anak sudah bisa membaca sendiri, tinggal menemaninya membaca.

\section{Dramatisi buku yang Anda baca}


Ubahlah cara baca ketika anak kurang atau tidak tertarik dengan buku yang dibacakan untuknya. Tambahkan kosakata dan kalimat yang menarik dan dramatisasilah cerita yang sedang dibacakan, caranya dengan gerakan-gerakan tubuh, mimik muka dan intonasi suara.

\section{Kesimpulan.}

Dengan berbagai hasil penelitian di atas, dengan demikian dapat disimpulkan bahwa Taman Bacaan Masyarakat dapat digunakan sebagai sarana untuk menumbuhkan minat baca. Ada beberapa cara untuk menumbuhkan minat baca, antara lain: 1) mengalokasikan waktu khusus untuk membaca; 2) Memanfaatkan waktu wenunggu. Waktu menunggu bisa dimanfaatkan untuk menumbuhkan kebiasaan membaca; 3) Meminta anak untuk bercerita tentang sesuatu yang telah dibacanya atau didengarnya membuat mereka lebih akrab dengan bahasa dan tutur kata; 4) Ciptakan perpustakaan keluarga; 5) Jika tidak mungkin, ajak anak ke perpustakaan; Dorong pula anak untuk rajin mengunjungi perpustakaan yang bisa mereka akses, baik perpustakaan sekolah, maupun Taman Baca Masyarakat. Oleh karena itu perlu dikelola dengan baik, sesuai dengan teori-teori pengelolaan perpustakaan yang dapat digunakan sebagai pedoman Taman Baca Masyarakat. Karena Taman Bacaan Masyrakat terletak dekat dengan masyarakat. 


\section{Daftar Pustaka}

Bhola, H.S.A., 1994. Sources Book For Literacy Work. Perspectives From The Grass Roots. Jessisa Kingsley Publisher/UNESCO Publishing, London.

Departemen Pendidikan Nasional. Pedoman Pengelolaan Taman Bacaan Masyarakat. Jakarta: Depdiknas, 20005.

Departemen Pendidikan Nasional. 2008. Naskah Akademik Pengelola Taman Bacaan Masyarakat $(T B M)$. Direktorat Jenderal Peningkatan Mutu Pendidik dan Tenaga Kependidikan, Direktorat Pendidik dan Tenaga Kependidikan Nonformal, Jakarta.

Dhawan, SM. 2014. Managing a library: Gibson, JamesL. 2000. Organisasi, Perilaku, Struktur dan Proses. Jakarta: Erlangga.

Hamid Muhhamad, dkk. 2010. Taman Bacaan Kreatif, Direktorat Pendidikan Masyarakat, Direktorat Jendral Pendidikan Nonformal dan informal, Kementrian Pendidikan Nasional, Jakarta.

Kementerian Pendidikan dan Kebudayaan. 2013. Petunjuk Teknis Pengajuan, Penyaluran, dan Pengelolaan Bantuan Taman Bacaan Masyarakat : Rintisan. Jakarta: Direktorat Pembinaan Pendidikan Masyarakat, Dirjen Pendidikan Anak Usia Dini, Nonformal, dan Informal.

Khoirudin, Arif; Imam Taulabi, Ali Imron. (2016). Menumbuhkan minat baca sejak dini di Taman Baca Masyarakat. Journal An-nafs: Vol. 1 No. 2 Desember.

Kusnadi, dkk. Pendidikan Keaksaraan, Filosofi, Stategi, Implementasi. Depatemen Pendidikan Nasional, Jakarta: 2005, hal. 41.

Nugroho, F dan Maureen, Irene Y, 2012. Pengelolaan Taman Bacaan Masyarakat sebagai penyelenggara pendidikan Nonformal di lingkungan masyarakat Rusun Bangunrejo, Surabaya. DocSlide. https://dokumen.tips/documents/pengelolaan-taman-bacaan-masyarakatsebagai-penyelenggara-pendidikan-nonformal.html

Rahmawan, Ary. (2013). 8 Cara Menumbuhkan Minat Baca. http://arryrahmawan.net/8-caramenumbuhkan-minat-baca. [Diunduh 3 Oktober, 2017]

Setiawan, Agus. (2017). Cara Paling Ampuh Agar Anak Ketagihan Membaca. http://bacakilat.com/cara-paling-ampuh-agar-anak-ketagihan-membaca/2017 [Diunduh 3 Oktober, 2017 ].

Yayasan Pengembangan Pendidikan Indonsia (YPPI). 2012. Pengertian, Tujuan, Fungsi dan Tugas Taman Bacaan Masyarakat (TBM). Surabaya : YPPI.

Sutarno. (2006). Perpustakaan dan Masyarakat. Jakarta: CV. Sagung Seto (edisi revisi). 
Suwanto, Sri Ati. ( 2009). Manajemen Perpustakaan : Tinjauan teoritis dan praktis. Makalah disampaikan pada Bimbingan Teknis Manajemen Perpustakan Perpusda Jateng, 10 - 20 Agustus. 